\title{
Calcite Dissolution by Brevibacterium sp. SOTI06: A Futuristic Approach for the Reclamation of Calcareous Sodic Soils
}

\author{
S. M. Tamilselvi ${ }^{1}$, Chitdeshwari Thiyagarajan ${ }^{2}$ and Sivakumar Uthandi ${ }^{1 *}$ \\ ${ }^{1}$ Biocatalysts Lab, Department of Agricultural Microbiology, Tamil Nadu Agricultural University, Coimbatore, India, \\ ${ }^{2}$ Department of Soil Science and Agricultural Chemistry, Tamil Nadu Agricultural University, Coimbatore, India
}

\section{OPEN ACCESS}

Edited by:

Kumar Krishnamurthy,

Tamil Nadu Agricultural University,

India

Reviewed by:

Balasubramanian Ramakrishnan, Indian Agricultural Research Institute,

India

G. Selvakumar,

ICAR-Indian Institute of Horticultural

Research, India

*Correspondence:

Sivakumar Uthand

usivakumartnau@gmail.com

Specialty section:

This article was submitted to

Plant Biotic Interactions,

a section of the journal

Frontiers in Plant Science

Received: 01 July 2016 Accepted: 21 November 2016 Published: 08 December 2016

Citation:

Tamilselvi SM, Thiyagarajan C and Uthandi S (2016) Calcite Dissolution

by Brevibacterium sp. SOTIO6: A

Futuristic Approach for the

Reclamation of Calcareous Sodic

Soils. Front. Plant Sci. 7:1828.

doi: 10.3389/fpls.2016.01828
Assessing the ability of soil microorganisms to dissolute poorly soluble native calcite to supply $\mathrm{Ca}^{2+}$ is a new area to be explored in reclaiming sodic soils by supplying adequate $\mathrm{Ca}^{2+}$ and reducing the recurrent sodicity. Hence, the present study aimed to isolate a calcite dissolving bacteria (CDB) from calcareous sodic soils and to understand the mechanism of calcite dissolution. Of the $33 \mathrm{CDB}$ isolates recovered from the calcareous sodic soils of Tamil Nadu (Coimbatore, Ramnad, and Trichy), 11 isolates were screened for calcite dissolution based on titratable acidity. 16S rRNA gene sequence analysis of the three best isolates viz., SORI09, SOTI05, and SOTI06 revealed 99\% similarity to Bacillus aryabhattai, $100 \%$ to B. megaterium, and $93 \%$ to Brevibacterium sp., respectively.

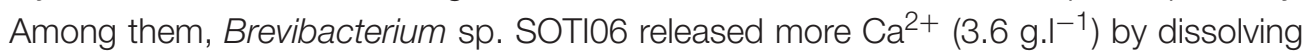
$18.6 \%$ of the native calcite. The spectral data of FTIR also showed reduction in the intensity of calcite (55.36-41.27) by the isolate at a wave number of $1636 \mathrm{~cm}^{-1}$ which confirmed the dissolution. Besides producing organic acids (gluconic acid and acetic acid), Brevibacterium sp. SOTI06 also produced siderophore (91.6\%) and extracellular polysaccharides (EPS, $13.3 \mu \mathrm{g} \cdot \mathrm{ml}^{-1}$ ) which might have enhanced the calcite dissolution.

Keywords: calcite dissolution, Brevibacterium sp., in-vitro analysis, calcareous soils, sodicity reclamation

\section{INTRODUCTION}

Soil degradation due to sodicity is the widest stress observed worldwide since the presence of high $\mathrm{Na}^{+}$concentration increases the inter particulate distances by enhancing the repulsive forces and therefore causes dispersion and loss of porosity, which consequently results in undesirable soil structure and reduced water permeability in the soil profile. Many of these soils are highly deficient in plant nutrients due to high $\mathrm{pH}$, exchangeable $\mathrm{Na}^{+}$, carbonates and bicarbonates, as a consequence crop production in these soils is also very poor (Murtaza et al., 2013; Tazeh et al., 2013). Hence, reclamation of these soils necessitates the removal of excess soluble $\mathrm{Na}^{+}$from the soil to facilitate better crop growth.

Most of the sodic soils are calcareous in nature contains inherent or precipitated sources of $\mathrm{Ca}^{2+}$ in the form of calcite within the soil profile and such soils are widely spread in arid and semi arid regions. Calcite dissolution results in the release of $\mathrm{Ca}^{2+}$ ions to the soil solution (Qadir et al., 2007) 
which replace $\mathrm{Na}^{+}$as detailed below (Qadir et al., 2005).

$$
2 \mathrm{Na}^{+}-\text {Clay }+\mathrm{Ca}^{2+} \Leftrightarrow \mathrm{Ca}^{2+}-\mathrm{Clay}+2 \mathrm{Na}^{+}
$$

Therefore, reclamation of calcareous sodic soils is possible when suitable amendments were identified and used at appropriate amounts. Generally amelioration of these soils has been achieved through the application of chemical amendments like gypsum (Abdel-Fattah, 2012; Cucci et al., 2012) as a direct source to supply sufficient $\mathrm{Ca}^{2+}$ for exchanging $\mathrm{Na}^{+}$. However, high cost and recurrent sodicity necessitates in finding out alternate sources and strategies. Phyto-remediation, a low cost technology involving different crops like kallar grass, sesbania, cotton, and halophytes like Aster sp., Atriplex sp., and Plantago sp. (Murtaza et al., 2009; Hasanuzzaman et al., 2014) helps to certain extent in lowering the sodicity but requires suitable plants, several growing seasons, and act only at limited depths (USEPA, 2000). Recently, microbial mediated calcite dissolution is gaining acceptance to reduce the sodicity.

However, most of the calcite dissolution mechanism has been studied without microorganisms (MacInnis and Brantley, 1992; Newton and Manning, 2002; Cucci et al., 2012) and only a very few reports have focused on the calcite dissolution by microorganisms (Lüttge and Conrad, 2004; Li et al., 2005; Jacobson and Wu, 2009; Subrahmanyam et al., 2012; Cacchio et al., 2014). Several mechanisms were reported for the extent of calcite dissolution such as acidification (Whitelaw et al., 1999) by producing organic acids (Goldstein, 1995; Fasim et al., 2002; Chen et al., 2006), inorganic acids (Hopkins and Whiting, 1916), chelating substances (Liermann et al., 2000; Yoshida et al., 2002), EPS (Yi et al., 2008), etc. Despite many reports on the mechanism of calcite dissolving microorganisms, it mainly centered around the production of organic acids like acetic acid, lactic acid, propionic acid, pyruvic acid, and succinic acid (Garcia-Pichel, 2006; Sulu-Gambari, 2011), enzymes like phosphatase (Ehrlich et al., 2008), EPS (Bissett et al., 2011) but none of them revealed the quantitative data on calcite dissolution. Hence, the present investigation aimed to isolate, identify an efficient $\mathrm{CDB}$ and measure their in-vitro calcite dissolution ability with an intention of using them for bio-remediating the calcareous sodic soils.

Abbreviations: -, Absence; +, Presence; $\mu$ l, Microliter; 16S rRNA, Ribosomal Ribo Nucleic Acid; Amp-X-gal-IPTG, Ampicillin, 5-bromo-4-chloro-3-indolyl- $\beta$ D-galactopyranosid and Isopropyl $\beta$-D-1-thiogalactopyranoside; Ar, Absorbance of reference; As, Absorbance of sample; FT-IR, Fourier Transformation Infra-Red spectrophotometer; $\mathrm{C}$, Control ; $\mathrm{Ca}^{2+}$, Calcium ions; $\mathrm{CaCO}_{3}$, Calcium carbonate; CAS, Chrome Azurol S; CD, Calcite dissolution; CDB, Calcite dissolving bacteria; $\mathrm{cm}$, Centimeter ; $\mathrm{CO}_{3}^{2-}$, Carbonate ; CS, Colony size; CZ, Clear zone; DB, DevenzeBruni; DNA, Deoxyribo Nucleic Acid; EPS, Exopolysaccharide; g, Gravity; g. ${ }^{-1}$, Gram per litre; $\mathrm{H}_{2} \mathrm{SO}_{4}$, Sulphuric acid; $\mathrm{HCl}$, Hydrochloric acid; $\mathrm{HCO}_{3}^{-}$, Bicarbonate; HPLC, High Performance Liquid Chromatography; IAA, Indole acetic acid; M, Molarity; min, Minute; ml, Millilitre; $\mathrm{Na}^{+}$, Sodium ion; $\mathrm{NaCl}$, Sodium chloride; $\mathrm{NaOH}$, Sodium hydroxide; $\mathrm{nm}$, Nanometer; OD, Optical density; PCR, Polymerase chain reaction; rpm, Rotation per minute; SI, Solubilization index; SOCE, Sodic soil Coimbatore district Enriched sample; SOCI, Sodic soil Coimbatore district Initial sample; SORE, Sodic soil Ramnad district Enriched sample; SORI, Sodic soil Ramnad district Initial sample; SOTE, Sodic soil Trichy district Enriched sample; SOTI, Sodic soil Trichy district Initial sample; T, Treated; TA, Titratable acidity; UV-VIS, Ultra violet-visible; Zn, Zinc; ZnO, Zinc oxide.

\section{MATERIALS AND METHODS}

\section{Materials}

Organic acids were from Sigma-Aldrich, India (Bengaluru) and other organic, inorganic analytical grade chemicals and agarose were from HI-Media Laboratories Pvt. Ltd. (Mumbai). Molecular biology chemicals were from New England Biolabs (Gurgaon, India) and Takara India (New Delhi).

\section{Media and Cultivation Conditions}

Unless and otherwise stated all the culture conditions were performed in $100 \mathrm{ml}$ of DB (Devenze-Bruni) medium in $250 \mathrm{ml}$ Erlenmeyer flasks (with final $\mathrm{OD}_{600} \mathrm{~nm}$ of 0.1) containing $\mathrm{CaCO}_{3}$ $\left(5\right.$ g.l $\left.{ }^{-1}\right)$ and incubated at $30^{\circ} \mathrm{C}$ under shaking at $120 \mathrm{rpm}$ for $24 \mathrm{~h}$. The cell free culture supernatant obtained by centrifugation at $8000 \mathrm{~g}$ for $15 \mathrm{~min}$ was used for analysis of $\mathrm{pH}, \mathrm{TA}, \mathrm{Ca}^{2+}$, $\mathrm{CaCO}_{3}, \mathrm{CO}_{3}^{2-}, \mathrm{HCO}_{3}^{-}$, acid phosphatase, organic acid, EPS, biofilm, and siderophore.

\section{Isolation, Screening, and Identification of Calcite Dissolving Bacteria \\ Soil Sampling and Enrichment}

Calcareous sodic soil samples collected from three districts of Tamil Nadu, India viz., Coimbatore (Altitude of $411 \mathrm{~m}$ above mean sea level, $11.0^{\circ} \mathrm{N}$ latitude and $76.9^{\circ} \mathrm{E}$ longitude), Ramnad (Altitude of $2 \mathrm{~m}, 9.3^{\circ} \mathrm{N}$ latitude and $78.8^{\circ} \mathrm{E}$ longitude), and Trichy (Altitude of $85 \mathrm{~m}, 10.7^{\circ} \mathrm{N}$ latitude and $78.7^{\circ} \mathrm{E}$ longitude), showed the free $\mathrm{CaCO}_{3}$ concentration of 7.2, 7.6, and 7.8\%, respectively and were stored at $4^{\circ} \mathrm{C}$. In order to isolate CDB, $100 \mathrm{~g}$ of each soil was enriched with $1 \% \mathrm{CaCO}_{3}$ individually and incubated for 2 weeks. Along with enriched soil samples, native, or initial soil samples were also used for the isolation of CDB.

\section{Isolation and Screening of CDB Isolates}

The CDB were isolated from both enriched and initial soil samples by serial dilution and plating technique using DB agar medium consisting of g..$^{-1}$ Glucose 5; Yeast extract 1; Peptone 1; $\mathrm{K}_{2} \mathrm{HPO}_{4} 0.4 ; \mathrm{MgSO}_{4} 0.01 ; \mathrm{NaCl} 5 ;\left(\mathrm{NH}_{4}\right)_{2} \mathrm{SO}_{4} 0.05 ; \mathrm{CaCO}_{3} 5$ and Agar 20 (Cacchio et al., 2004). The CD positive isolates picked based on clear zone formation around the colony were further confirmed by point inoculation onto the same medium. The solubilization index (SI) of the individual isolates was determined by measuring the ratio of the clear zone and colony size on DB agar plate by using the following formula:

$$
\begin{aligned}
\text { Solubilization index }= & \frac{\text { Clear zone }+ \text { Colony size }}{\text { Colony size }}---[\text { F1 }] \\
& \text { (Mihalache et al., 2015) }
\end{aligned}
$$

Secondary screening of positive isolates was carried out by calculating titratable acidity (TA) from $24 \mathrm{~h}$ old cultures grown in DB liquid medium. One milliliter of the cell free culture supernatant was titrated against $10 \mathrm{mM} \mathrm{NaOH}$ in the presence of phenolphthalein indicator until the appearance of pink color (Whitelaw et al., 1999). 


\section{Identification of CDB Isolates by $16 \mathrm{~S}$ rRNA}

Total genomic DNA of the selected isolates were extracted and purified using the method described by Clark (2013). $\mathrm{CDB}$ isolates were identified by amplification of $16 \mathrm{~S}$ rRNA gene using 27F (5' AGAGTTTGATCCTGGCTCAG $\left.3^{\prime}\right)$ and 1492R (5' GGTTACCTTGTTACGACTT $3^{\prime}$ ) primers with the PCR conditions of initial denaturation at $95^{\circ} \mathrm{C}$ for $10 \mathrm{~min}$ followed by 35 cycles of denaturation at $94^{\circ} \mathrm{C}$ for $30 \mathrm{~s}$, annealing at $55^{\circ} \mathrm{C}$ for $30 \mathrm{~s}$ and extension at $72^{\circ} \mathrm{C}$ for $1 \mathrm{~min}$, followed by a final extension at $72^{\circ} \mathrm{C}$ for $15 \mathrm{~min}$ in a thermo cycler (BioRad, USA). Then, the PCR products were cloned into the pGEMT vector and transformed into chemically competent E. coli DH5 $\alpha$ cells (Sambrook et al., 1989). Positive clones were selected based on bluewhite screening from Amp-X-gal-IPTG plates and further confirmed by colony lysis PCR using M13 forward ( $5^{\prime}$ GTAAAACGACGGCCAGT $\left.3^{\prime}\right)$ and reverse primers $\left(5^{\prime}\right.$ AACAGCTATGACCATG $3^{\prime}$ ). The positive clones were sequenced [Bioserve Biotechnologies (I) Pvt. Ltd., Hyderabad, India]. 16S rRNA gene sequence obtained for each clone was aligned and compared with available sequences of bacterial lineage using Ez Taxon-e (http://eztaxon-e.ezbiocloud.net/). A phylogenetic tree was constructed using MEGA 6 program (Tamura et al., 2013) and their grouping sequence was based on confidence values obtained by bootstrap analysis of 1000 replicates.

\section{Surface Attachment of Brevibacterium sp. SOTI06}

\section{Biofilm (Planktonic) Formation}

One day old Brevibacterium sp. SOTI06 culture $(0.1 \mathrm{ml})$ was taken into 96 well micro titre plate, covered and incubated at $30^{\circ} \mathrm{C}$ for $24 \mathrm{~h}$. After incubation, the plates were washed thoroughly with sterile distilled water and air dried. One hundred and fifty microliters of $0.1 \%$ crystal violet was added to each well and incubated for $45 \mathrm{~min}$. The excess stain was removed by sterile distilled water and air dried. Subsequently, $200 \mu \mathrm{l}$ of $95 \%$ ethanol was added to each well and plates were incubated for $10-15 \mathrm{~min}$. Contents of each well were mixed and $125 \mu \mathrm{l}$ of the crystal violet/ethanol solution was transferred to a separate clear bottom well and optical density was measured at $600 \mathrm{~nm}$ using micro plate reader (Molecular Devices LLC, USA; Djordjevic et al., 2002).

\section{EPS Production}

Brevibacterium sp. SOTI06 was cultured in DB liquid medium supplemented with $\mathrm{CaCO}_{3}\left(5\right.$ g. $\left.1^{-1}\right)$ and incubated at $30^{\circ} \mathrm{C}$ for $24 \mathrm{~h}$ at $120 \mathrm{rpm}$. The culture was centrifuged at $4000 \mathrm{~g}$ for $15 \mathrm{~min}$ and the pellet was used for estimation of EPS by suspending the pellet with $5 \mathrm{ml}$ distilled water and $5 \mathrm{ml} 0.1 \mathrm{~N}$ $\mathrm{KOH}$. The contents were boiled at $100^{\circ} \mathrm{C}$ for $10 \mathrm{~min}$. After cooling, the suspension was neutralized with $1 \mathrm{M} \mathrm{HCl}$ and $1 \mathrm{ml}$ of suspension, was mixed with $5 \mathrm{ml}$ Anthrone reagent and the intensity of color was measured at $620 \mathrm{~nm}$ in UV-VIS spectrophotometer (Systronics, India, DuBois et al., 1956).

\section{Calcite Dissolution (CD) Potential of Brevibacterium sp. SOTI06 \\ Estimation of Dissolution}

In order to quantify CD ability of Brevibacterium sp. SOTI06 grown in DB liquid medium, cell free culture supernatant obtained at periodical intervals were subjected to the analysis of calcium (Jackson, 2005), calcium carbonate (Piper, 1944), carbonates, bicarbonates (Richards, 1954), phosphatase (Tabatabai and Bremner, 1969), protein concentration (Bradford, 1976), pH, and TA.

\section{Quantification of Organic Acid Production}

Organic acid production was estimated from $24 \mathrm{~h}$ old culture by injecting $30 \mu \mathrm{l}$ of $0.2 \mu \mathrm{m}$ filtered cell free supernatant in HPLC with a UV detector set at $210 \mathrm{~nm}$. The organic separation was carried out on Cosmosil packed column (Nacalai Tesque, Japan) with $10.8 \%$ Acetonitrile in $0.0035 \mathrm{M}$ $\mathrm{H}_{2} \mathrm{SO}_{4}$ as mobile phase at a flow rate of $0.6 \mathrm{ml} \cdot \mathrm{min}^{-1}$ (Chen et al., 2006). The data integration and analysis was done using Autochrom software. HPLC grade organic acids kit (No.47264 from Sigma Aldrich, USA) was used as standards.

\section{Analysis of CD by ATR-FT-IR}

FT-IR spectrum of $\mathrm{CaCO}_{3}$ in the spent medium by Brevibacterium sp. SOTI06 was recorded in JASCO FTIR 6800 fitted with diamond enabled Attenuated Total Reflectance (ATR) sample holder and a DLaTgs detector and compared with $\mathrm{CaCO}_{3}$. The wavelength range was from 400 to $4000 \mathrm{~cm}^{-1}$. Spectral measurements were done in triplicates and 64 scans were recorded for all samples at a $4 \mathrm{~cm}^{-1}$ resolution.

\section{Siderophore Production}

Siderophore production of Brevibacterium sp. SOTI06 was observed by point inoculation with fresh culture onto Chrome Azural S (CAS) agar plate and incubated for $48 \mathrm{~h}$ at $30^{\circ} \mathrm{C}$ (Schwyn and Neilands, 1987), which was further confirmed by broth assay. The assay was carried out by mixing the culture supernatant $(0.5 \mathrm{ml})$ with $0.5 \mathrm{ml}$ CAS reagent and the absorbance was measured at $630 \mathrm{~nm}$ against a reference consisting of uninoculated liquid medium. Siderophore content was estimated using the formula:

Per cent siderophore units $=(\mathrm{Ar}-\mathrm{As} / \mathrm{Ar}) \times 100----[\mathrm{F} 2]$ (Payne, 1994)

Where, Ar is the absorbance of reference and As is the absorbance of sample.

\section{Statistical Analysis}

All the data were subjected to statistical analysis in Microsoft Excel (Windows 2007) add-in with XLSTAT version 2010.5.05 (XLSTAT, 2010). 


\section{RESULTS}

\section{Isolation, Screening, and Identification of CDB Isolates}

A total of 33 isolates (17 from native and 16 from enriched soils) showing clear zone (Figure 1) in DB medium was evaluated for calcite solubilization index (SI) which varied from 0.37 to 6.67 . Among the three soils, SI values were higher with the isolates from Trichy soil than in Coimbatore and Ramnad soils. Higher SI values were observed in native isolates (0.88-6.67) compared to isolates from enriched soils (0.37-2.33). Among the isolates, SOTI06 showed maximum calcite SI (6.67) followed by SORI01 (3.70) and SOTI05 (2.10) which were from initial soils. On the other hand, maximum SI of 2.33 was observed in enriched isolate SOCE29. The least SI was recorded for the isolates SOCE22 and SOCE33 (Figure 2). Top 11 isolates having the highest SI were evaluated for TA production ability. Among them, eight isolates produced TA in the range of $0.05-0.12$ g. $1^{-1}$ and three isolates, SORI09, SOTI05, and SOTI06 produced maximum TA of 0.81 , 0.60 , and $1.41 \mathrm{~g} .1^{-1}$, respectively (Figure 3).

Identification of the three promising isolates based on 16S rRNA gene sequence revealed that SOTI06 showed 93\% similarity to Brevibacterium halotolerans DSM 8802 as their closest organism. SOTI05 showed $100 \%$ similarity to Bacillus megaterium NBRC 15308 and SORI09 showed 99\% similarity to Bacillus aryabhattai B8W22, respectively (Figure 4). Genbank accessions for 16S rRNA gene sequence of these isolates, SOTI06, SOTI05, and SORI09 were KX443712, KX443711, and KX443710, respectively.

\section{Surface Attachment of Brevibacterium sp. SOTI06}

Microbial mediated calcite dissolution starts with surface attachment of the bacteria by means of biofilm formation and EPS production subsequently the mineral dissolution by secreting organic acids, siderophore, and phosphatase. Brevibacterium sp. SOTI06 was able to form higher amount of biofilm when supplemented with $\mathrm{CaCO}_{3}$ than medium without $\mathrm{CaCO}_{3}$ which was evidenced with the increase in $\mathrm{OD}_{600 \mathrm{~nm}}$ of former (0.21) than later (0.16). Similarly,

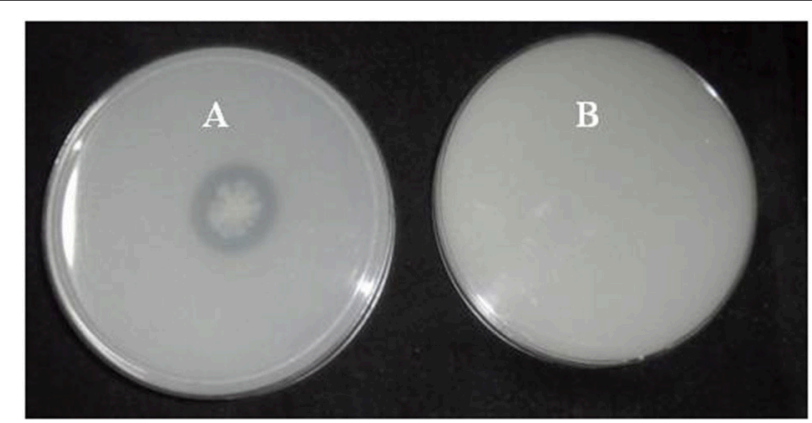

FIGURE 1 | Clear zone formation by Brevibacterium sp. SOTI06. The bacterium forms a clear zone around the colony on DB medium in the presence of $\mathrm{CaCO}_{3}$ (A) indicating calcite dissolution was compared with control plate (B) the production of EPS was higher $\left(13.3 \mu \mathrm{g} \cdot \mathrm{ml}^{-1}\right)$ in the medium supplemented with $\mathrm{CaCO}_{3}$ than in control $\left(4.39 \mu \mathrm{g} \cdot \mathrm{ml}^{-1}\right)$.

\section{Calcite Dissolution}

\section{Estimation of Dissolution}

The calcite dissolution behavior of Brevibacterium sp. SOTI06 was estimated over a period of 5 days by measuring the $\mathrm{pH}$, TA, phosphatase, $\mathrm{CaCO}_{3}, \mathrm{Ca}^{2+}, \mathrm{CO}_{3}^{2-}$, and $\mathrm{HCO}_{3}^{-}$content in the medium. The results revealed that $\mathrm{pH}$ decreased gradually from 8.02 to 5.72 until 4th day and there after increased to 6.60 on 5 th day. On contrary, TA and phosphatase activity showed an increasing trend from 0 to 4 th day and decreased later. Production of TA started on 1 st day $\left(0.93 \mathrm{~g} . \mathrm{l}^{-1}\right)$ and almost doubled on 2 nd day $\left(1.63 \mathrm{~g} . \mathrm{l}^{-1}\right)$, further an increment in TA was noticed up to 4 th day (1.95 g. $\left.\mathrm{l}^{-1}\right)$ and suddenly dropped to $1.33 \mathrm{~g} .1^{-1}$ at 5 th day. But, the phosphatase activity was linearly increased from 1st day (19.7 U. $\mathrm{ml}^{-1}$ ) onwards, reaching maximum up to 4 th day $\left(91.8 \mathrm{U} \cdot \mathrm{ml}^{-1}\right.$ ) and reduced to 70.7 U.ml $\mathrm{m}^{-1}$ on 5 th day (Figure 5A). The protein concentration was also increased from 1 st day $\left(10.0\right.$ g. $\left.1^{-1}\right)$ to 4 th day $\left(34.4\right.$ g. $\left.1^{-1}\right)$ and declined on 5 th day $\left(26.7\right.$ g. $\left.1^{-1}\right)$.

The supplemented calcium carbonate content was slowly decreased from 5.0 to $4.07 \mathrm{~g} .1^{-1}$ with simultaneous increase in calcium and bicarbonate concentrations. The release of $\mathrm{Ca}^{2+}$ into the solution was higher than bicarbonate ions. A minimal amount of calcium $\left(0.04 \mathrm{~g} . \mathrm{l}^{-1}\right)$ and no bicarbonates were released on 0th day and thereafter, the release of calcium content was higher until 5th day (3.60 g. $\left.\mathrm{l}^{-1}\right)$. However, the bicarbonate content was increased until 4th day reaching the maximum of 0.65 g..$^{-1}$ and decreased later. Overall, Brevibacterium sp. SOTI06 was capable of dissolving $18.6 \%$ of calcite within 5 days of incubation (Figure 5B).

\section{Organic Acid Production}

Supplementation of $\mathrm{CaCO}_{3}$ to Brevibacterium sp. SOTI06 resulted in the production of organic acids such as gluconic acid, acetic acid, fumaric acid, and phytic acid. Among the secreted organic acids, gluconic acid was the predominant one $\left(3.24 \mathrm{mg} \cdot \mathrm{ml}^{-1}\right)$ followed by acetic acid $\left(3.17 \mathrm{mg} \cdot \mathrm{ml}^{-1}\right)$. A minimal amount of phytic acid $\left(10 \mu \mathrm{g} \cdot \mathrm{ml}^{-1}\right)$ and fumaric acid $\left(7 \mu \mathrm{g} \cdot \mathrm{ml}^{-1}\right)$ was also recorded in the medium enriched with $\mathrm{CaCO}_{3}$ (Figure 6). Conversely, the medium without $\mathrm{CaCO}_{3}$ resulted in lesser production of acetic acid $\left(0.92 \mathrm{mg} \cdot \mathrm{ml}^{-1}\right)$ and fumaric acid $\left(0.25 \mu \mathrm{g} \cdot \mathrm{ml}^{-1}\right)$ whereas; the release of predominant gluconic acid was not observed (data not given).

\section{FT-IR Analysis}

FT-IR spectra of calcite dissolution by Brevibacterium sp. SOTI06 was compared with uninoculated control (Figure 7) and the spectral data showed changes in vibration and alteration of structure with reduced intensity (55.36-41.27\%) which confirmed the calcite dissolution by bacterium $\left(1636 \mathrm{~cm}^{-1}\right)$. Further, the presence of additional two new peaks at wave number of 1222 and $1370 \mathrm{~cm}^{-1}$ with strong $\mathrm{OH}$ groups was observed in treated sample (Table 1). 


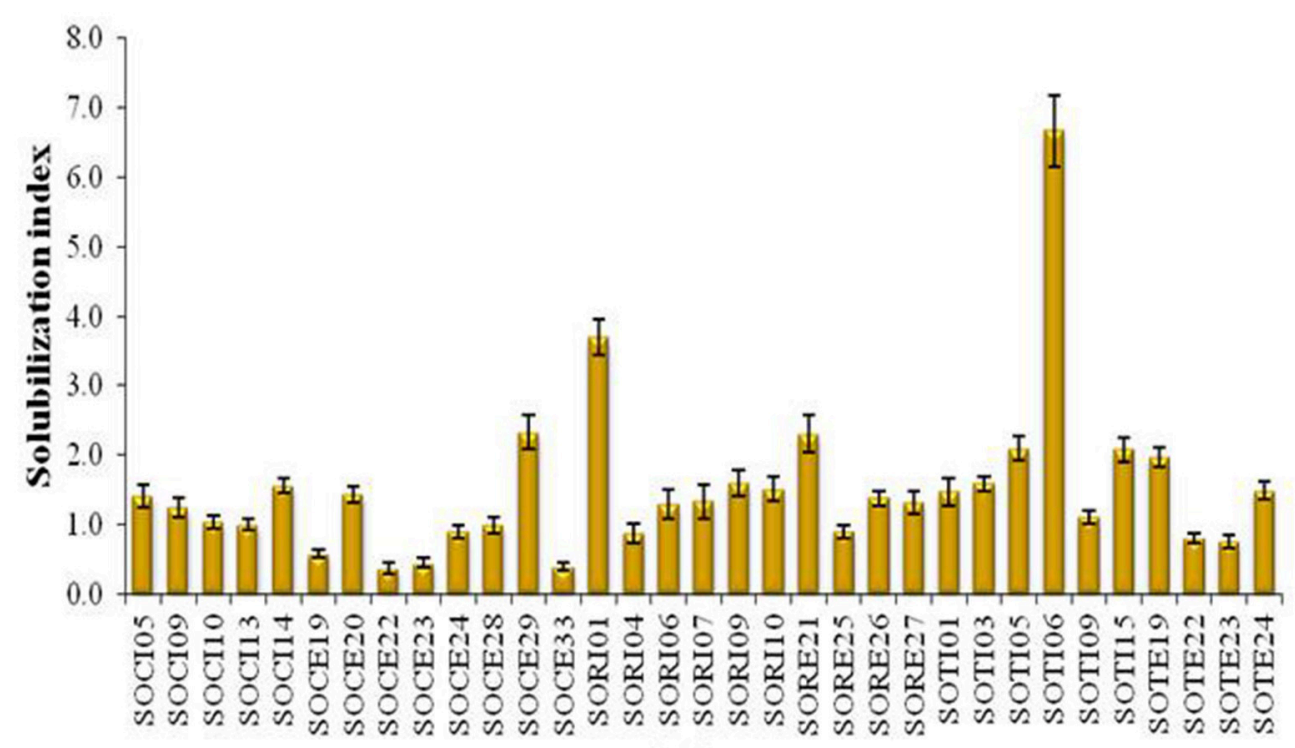

Isolates

FIGURE 2 | Solubilization index of CDB isolates obtained from Tamil Nadu. The SI was estimated for the isolates obtained from both initial and enriched soils of Coimbatore, Ramnad, and Trichy districts of Tamil Nadu. Means of three replicate values plotted and error bars indicate the standard error.

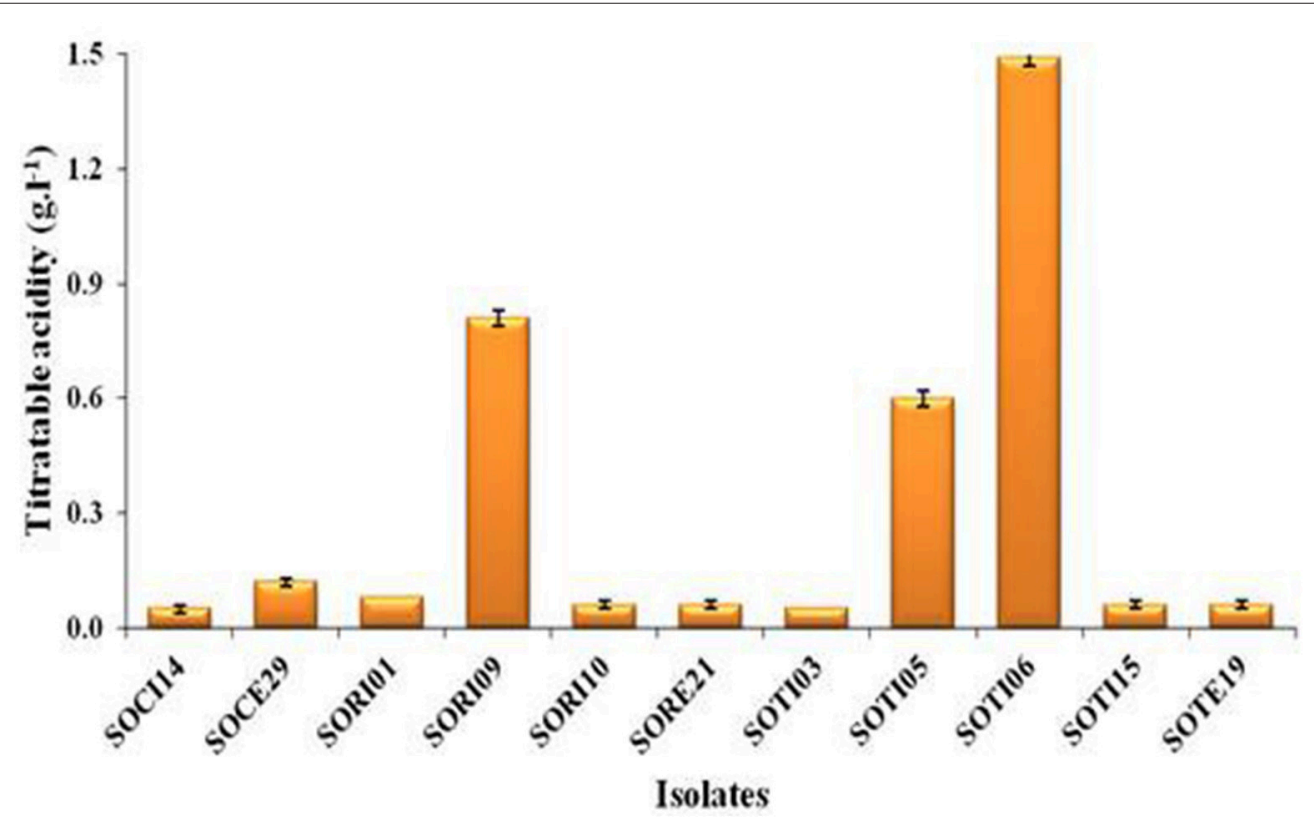

FIGURE 3 | Titratable acidity of selected CDB isolates. The TA was determined from the culture supernatant of the isolates and the content was higher when these isolates produce acids. Means of three replicate values plotted and error bars indicate the standard error.

\section{Siderophore Production}

The development of yellow halo around the colonies in CAS plate was confirmed by broth assay showed that Brevibacterium sp. SOTI06 produced siderophore both in $\mathrm{CaCO}_{3}$ amended as well as unamended liquid medium was evidenced by a change of color from blue to yellow (Figure 8). But, their production was higher in amended medium registering 91.6 per cent siderophore units than the control $(88.6 \%)$.

\section{DISCUSSION}

Salt affected soils are wide spread in many arid and semiarid regions which are the major constraints for agricultural 


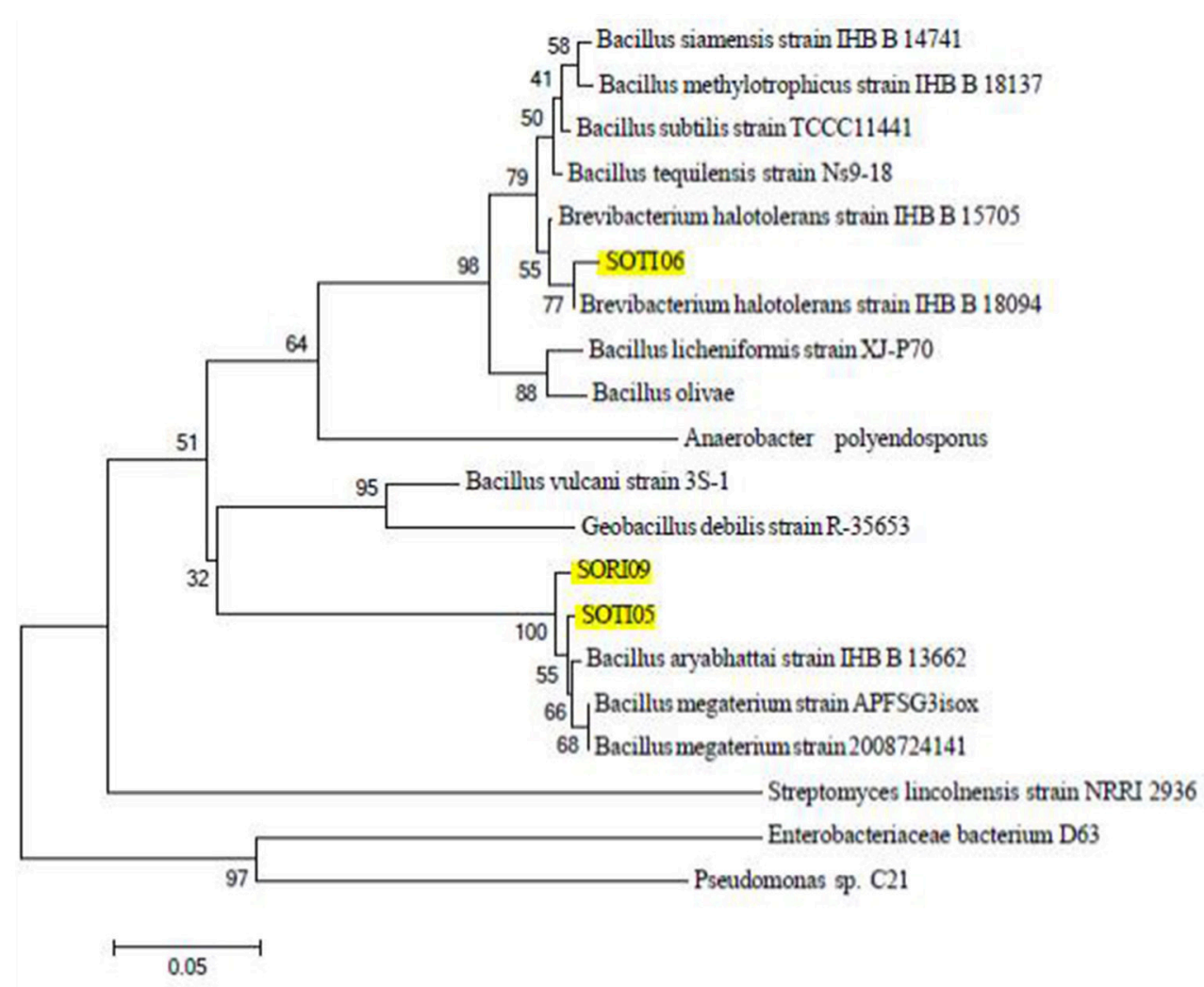

FIGURE 4 | Phylogeny of CDB isolates. The phylogenetic relationship of the selected isolates (SORI09, SOTI05, and SOTI06) and their related strains based on $16 \mathrm{~S}$ rRNA sequence was constructed using Mega 6. Numbers at nodes indicate the level of bootstrap support (1000 replications). Scale bar indicates base substitutions/1000 bases.

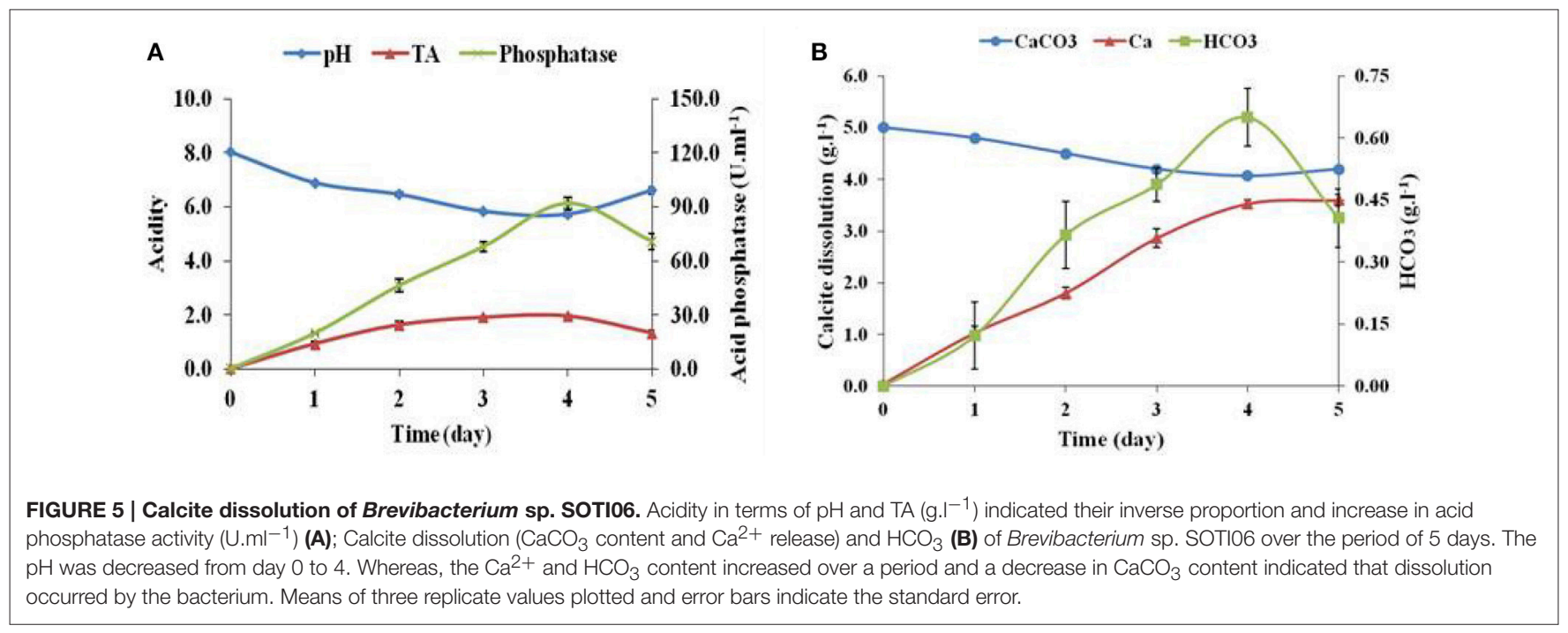

expansion and productivity. The main reason for the increased sodicity is due to faulty irrigation and drainage practices which leads to soil degradation and ultimately reduces crop yield (Sumner, 1993; Sharma and Rao, 1998; Haynes and Hamilton, 1999; Gharaibeh et al., 2011). In order to reduce the sodicity in calcareous soils, the native calcite need to be dissolved to release adequate $\mathrm{Ca}^{2+}$ so as to replace the $\mathrm{Na}^{+}$ions, which can be leached out through irrigation (Oster, 1982; Shainberg et al., 1989; Qadir and Oster, 2002). Microbial mediated calcite dissolution studies are very sparse in the literature 


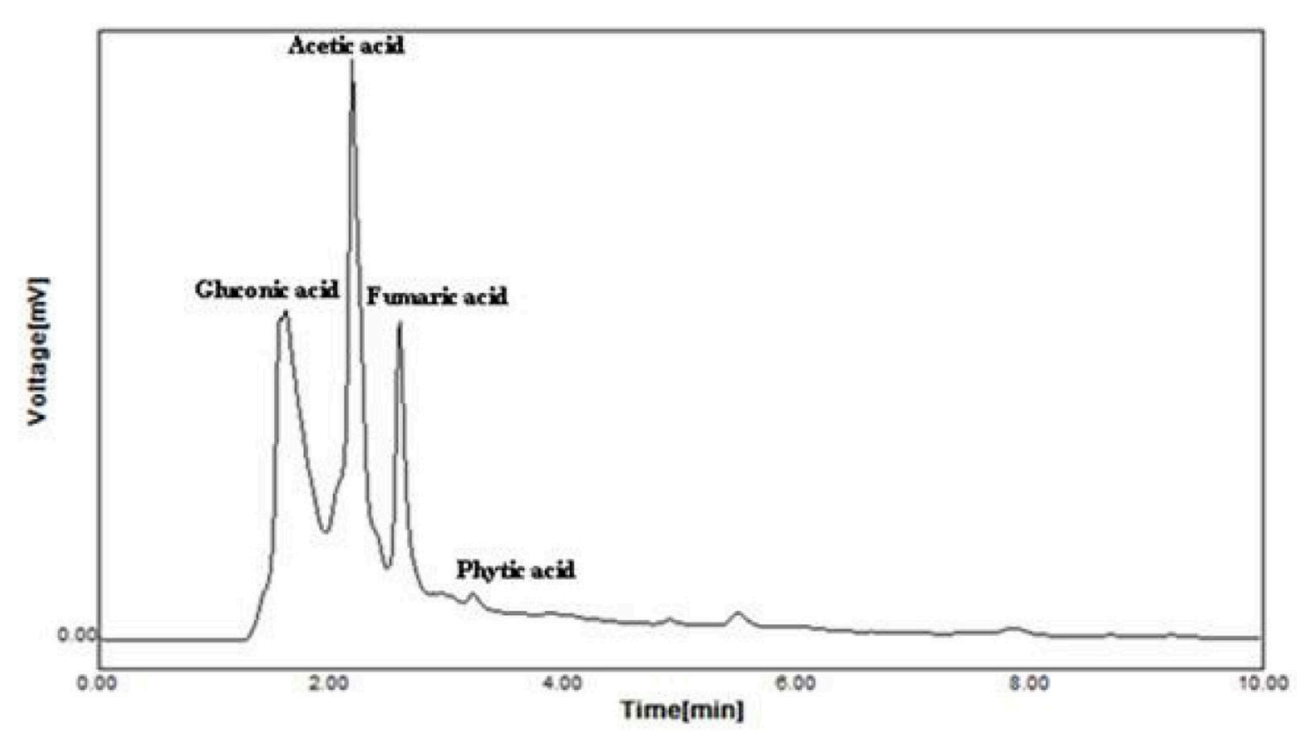

FIGURE 6 | Organic acid production by Brevibacterium sp. SOTI06. The organic acid production was estimated for the culture supernatant using HPLC analysis and the chromatogram showed the acids production. The standards used were gluconic acid, acetic acid, fumaric acid, and phytic acid.

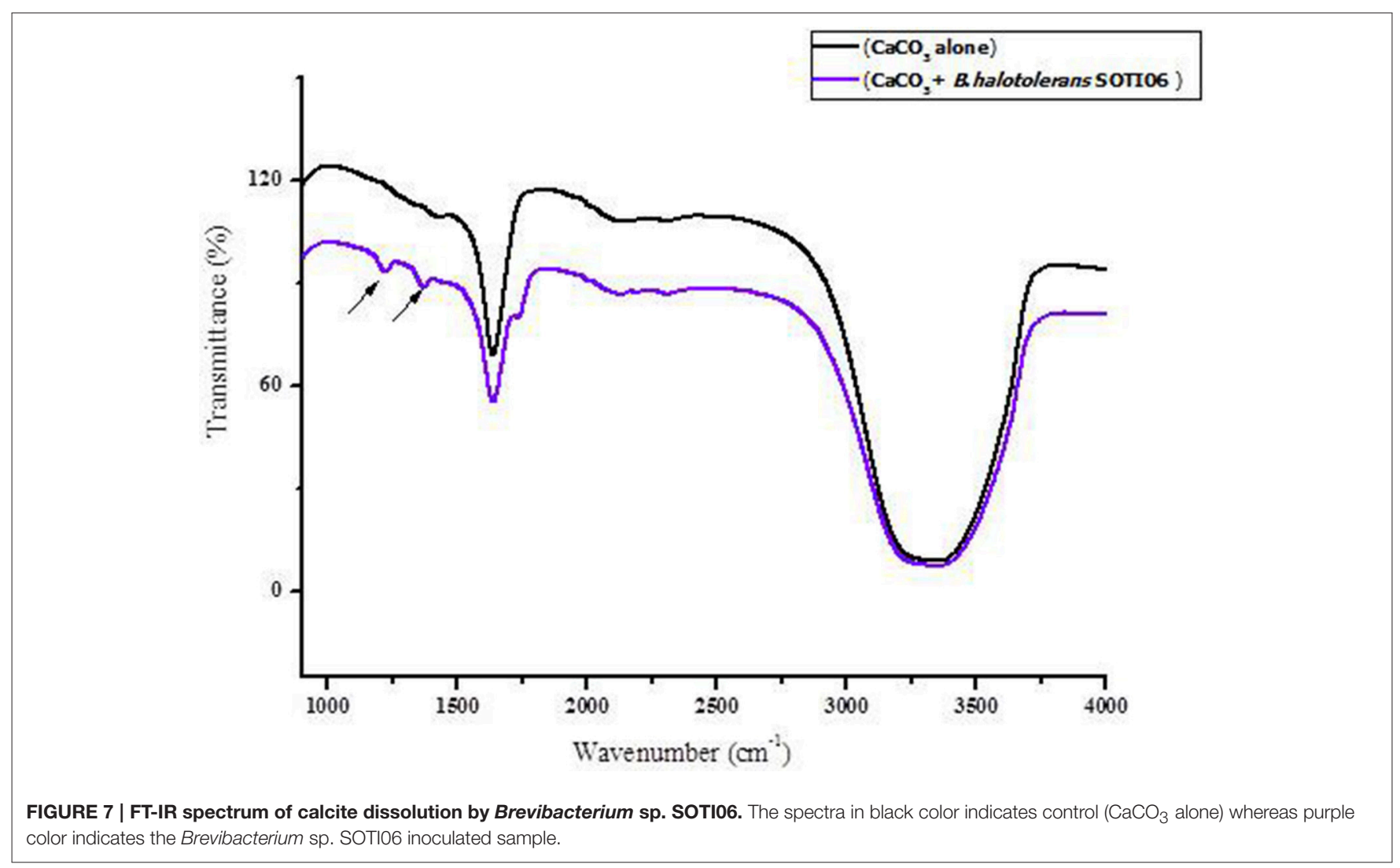

for instance, calcite and dolomite dissolution was studied in Shewenella oeindeisis MR1 (Davis et al., 2007), Bacillus subtilis, and Burkholderia fungorum (Friis et al., 2003; Jacobson and Wu, 2009). Recently, Brevibacterium sp. was isolated from Krast caves and reported their calcite dissolution ability (Sonntag, 2015). Hence, it is imperative to develop calcite dissolving microbes and understanding its mechanisms of dissolution so as to reclaim the calcareous sodic soils effectively. In this contest, the present 
TABLE 1 | FTIR spectrum of Brevibacterium sp. SOTI06.

\begin{tabular}{|c|c|c|c|c|c|}
\hline Sample & Wavenumber $\left(\mathrm{cm}^{-1}\right)$ & Functional group & Bond & Intensity & Mode \\
\hline Control & 1636 & Alkene & $\mathrm{C}=\mathrm{C}$ & Variable & Stretching (non-conjugated $\mathrm{C}=\mathrm{C}$ ) \\
\hline \multirow[t]{2}{*}{ Treated } & 1636 & Alkene & $\mathrm{C}=\mathrm{C}$ & Variable & Stretching (non-conjugated $\mathrm{C}=\mathrm{C}$ ) \\
\hline & 1370 & $\mathrm{OH}$ & $\mathrm{NH}$ & Medium to weak & Amide III combination of $\mathrm{C}-\mathrm{N}$ stretching and $\mathrm{N}-\mathrm{H}$ bending \\
\hline
\end{tabular}

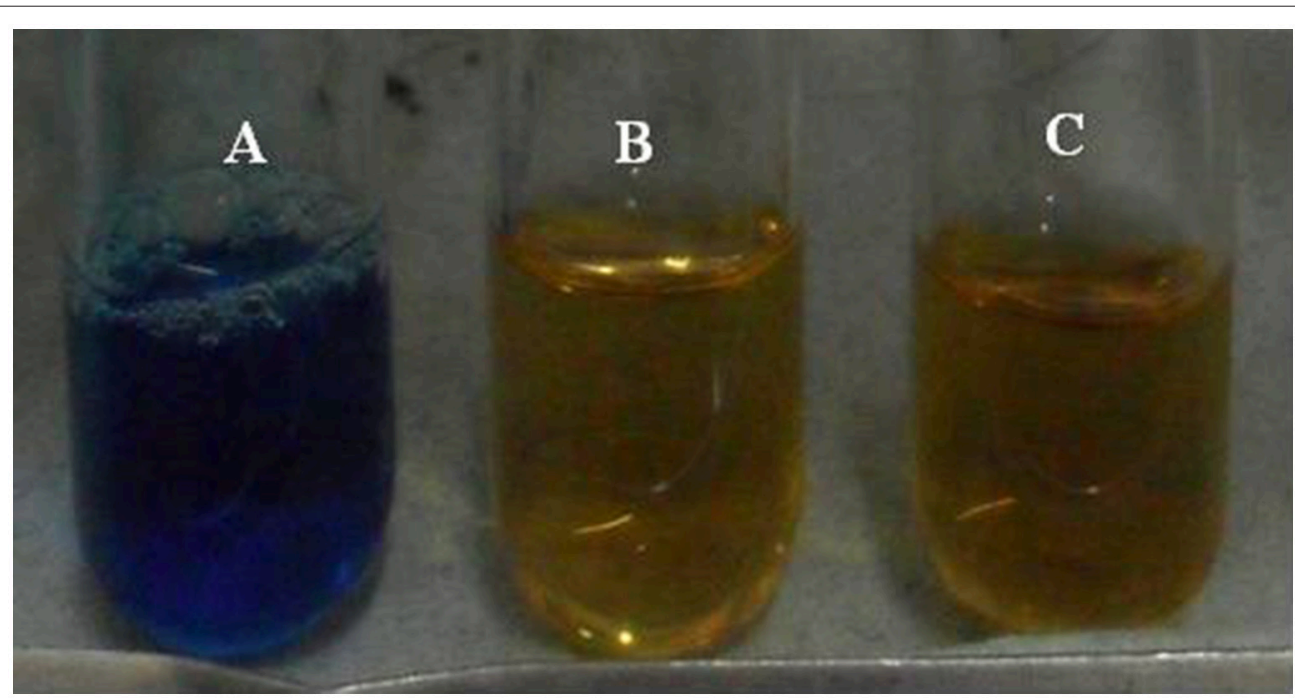

FIGURE 8 | Siderophore production by Brevibacterium sp. SOTI06. The siderophore production was estimated by CAS assay with reference (A) in the presence (B) and absence (C) of $\mathrm{CaCO}_{3}$. The change of color from blue to yellow indicated the siderophore production.

study on isolation, screening and identification of CDB and understanding the mechanism underpinning calcite dissolution is significant.

The present investigation indicated SOTI06 as the best isolate based on the calcite dissolving ability and titratable acidity. The $16 \mathrm{~S}$ rRNA gene sequence of the newly isolated bacterial isolate SOTI06 was analyzed to establish its phylogenetic relationship, which showed only $93 \%$ similarity with $B$. halotolerans strain DSM 8802 suggesting that this isolate might be a new one and needs further systematic and taxonomical studies to reveal its novelty.

Calcite dissolution is regulated by a wide range of molecules like organic acids, amino acids and these molecules inhibit calcite growth thereby promoting dissolution (Teng et al., 2006). The growth, planktonic form of biofilm formation and EPS production are the mechanisms by which microorganisms attached to the mineral surface (Banfield et al., 1999; Kraemer, 2004; Peacock et al., 2004; Buss et al., 2007; Yi et al., 2008; Shirvani and Nourbakhsh, 2010; Parrello et al., 2016) and helps dissolution. In the present study, the CDB isolate Brevibacterium sp. SOTI06 produced considerable amount of EPS and planktonic form of biofilm in the presence of calcite suggesting its possible attachment to dissolute calcite as evidenced by Bissett et al. (2011).

A reduction in $\mathrm{pH}$ as induced by the production of TA by Brevibacterium sp. SOTI06 determines the solubility of minerals (Whitelaw et al., 1999; Ogbo, 2010; Barroso and Nahas, 2013). The trend of decrease in calcium carbonate content and increase in $\mathrm{Ca}^{2+}$ supply from first day onwards indicates that the dissolution process initiated upon inoculation as evidenced from the gluconic acid production by Brevibacterium sp. SOTI06 and suggests that the gluconic acid might be the predominant one involved in calcite dissolution. The increase in calcium carbonate content on fifth day might be due to precipitation and these results are in accordance with Subrahmanyam (2013). In multicellular organisms like sponges, the cellular attachment on mineral surface, penetration, and dissolution of calcareous substrates are mediated by many enzymatic activities particularly carbonic anhydrase and acid phosphatases (Kreitzman and Fritz, 1970). In the present CD experiment, the enhanced acid phosphatase activity coupled with drop in $\mathrm{pH}, \mathrm{CaCO}_{3}$, and release of $\mathrm{Ca}^{2+}$ explains the role of this enzyme on supplying calcium through effective calcite dissolution

The FT-IR results suggest that bacterial dissolution might have altered the structure of calcite and resulted in vibration change. Since the Brevibacterium sp. SOTI06 secreted gluconic acid and other acids, which might have facilitated the release of $\mathrm{Ca}^{2+}$ from calcite and results in overall mass reduction. Such reduction was evident in the FT-IR spectra of treated samples and also the results with measurement of $\mathrm{Ca}^{2+}$ supported this phenomenon. The presence of two additional 
peaks with strong $\mathrm{OH}$ groups might be attributed to acids secreted by Brevibacterium sp. SOTI06. From the FT-IR study, the dissolution behavior and acid secretion of Brevibacterium sp. SOTI06 was confirmed.

Though, the present study showed calcite dissolution of the isolate under in vitro condition, the potential of this bacterium is yet to be evaluated in detail under in vivo condition to remediate the calcareous sodic soils.

\section{CONCLUSION}

The present study reported a calcite dissolving Brevibacterium sp. SOTI06 with a potential to dissolute $18 \%$ calcite with a simultaneous release of $\mathrm{Ca}^{2+}$ ions under in vitro conditions. Gluconic acid production, biofilm formation, production of siderophore, and EPS by Brevibacterium sp. SOTI06 might be the possible mechanisms attributed to the dissolution of calcite.

\section{REFERENCES}

Abdel-Fattah, M. K. (2012). Role of gypsum and compost in reclaiming salinesodic soils. J. Agric. Vet. Sci. 1, 30-38. doi: 10.9790/2380-0133038

Banfield, J. F., Barker, W. W., Welch, S. A., and Taunton, A. (1999). Biological impact on mineral dissolution: application of the lichen model to understanding mineral weathering in the rhizosphere. Proc. Natl. Acad. Sci. U.S.A. 96, 3404-3411. doi: 10.1073/pnas.96.7.3404

Barroso, C. B., and Nahas, E. (2013). Enhanced solubilization of iron and calcium phosphates by Aspergillus niger by the addition of alcohols. Braz. Arch. Biol. Technol. 56, 181-189. doi: 10.1590/S1516-89132013000200003

Bissett, A., Neu, T. R., and de Beer, D. d. (2011). Dissolution of calcite in the twilight zone: bacterial control of dissolution of sinking planktonic carbonates is unlikely. PLoS ONE 6:e26404. doi: 10.1371/journal.pone.0026404

Bradford, M. M. (1976). A rapid and sensitive method for the quantitation of microgram quantities of protein utilizing the principle of protein-dye binding. Anal. Biochem. 72, 248-254. doi: 10.1016/0003-2697(76)90527-3

Buss, H. L., Lüttge, A., and Brantley, S. L. (2007). Etch pit formation on iron silicate surfaces during siderophore-promoted dissolution. Chem. Geol. 240, 326-342. doi: 10.1016/j.chemgeo.2007.03.003

Cacchio, P., Contento, R., Ercole, C., Cappuccio, G., Martinez, M. P., and Lepidi, A. (2004). Involvement of microorganisms in the formation of carbonate speleothems in the Cervo Cave (L'Aquila-Italy). Geomicrobiol. J. 21, 497-509. doi: 10.1080/01490450490888109

Cacchio, P., Ferrini, G., Ercole, C., Del Gallo, M., and Lepidi, A. (2014). Biogenicity and characterization of moonmilk in the Grotta Nera (Majella National Park, Abruzzi, Central Italy). J. Cave Karst Stud. 76, 88. doi: 10.4311/2012M B0275

Chen, Y. P., Rekha, P. D., Arun, A. B., Shen, F. T., Lai, W. A., and Young, C. C. (2006). Phosphate solubilizing bacteria from subtropical soil and their tricalcium phosphate solubilizing abilities. Appl. Soil Ecol. 34, 33-41. doi: 10.1016/j.apsoil.2005.12.002

Clark, M. S. (2013). Plant Molecular Biology - A Laboratory Manual. Cambridge, UK: Springer Science \& Business Media.

Cucci, G., Lacolla, G., Pallara, M., and Laviano, R. (2012). Reclamation of saline and saline-sodic soils using gypsum and leaching water. Afr. J. Agric. Res. 7, 6508-6514. doi: 10.5897/AJAR12.1559

Davis, K. J., Nealson, K. H., and Lüttge, A. (2007). Calcite and dolomite dissolution rates in the context of microbe-mineral surface interactions. Geobiology 5, 191-205. doi: 10.1111/j.1472-4669.2007.00112.x

Djordjevic, D., Wiedmann, M., and McLandsborough, L. A. (2002). Microtiter plate assay for assessment of listeria monocytogenes biofilm formation. Appl. Environ. Microbiol. 68, 2950-2958. doi: 10.1128/AEM.68.6.2950-295 8.2002

\section{AUTHOR CONTRIBUTIONS}

SU and CT conceived the idea and designed experiments. ST conducted the experiments, analyzed the data and helped in drafting the manuscript. SU finalized the results after compiling data and completed the manuscript preparation.

\section{ACKNOWLEDGMENTS}

Fellowship support from Department of Biotechnology, Ministry of Science and Technology, Government of India, New Delhi for the scheme "Bioremediation of degraded calcareous Sodic and Saline-Sodic soils" (BT/PR7187/BCE/8/935/2012) offered to ST is gratefully acknowledged. The authors also acknowledge the additional financial support by the Ministry of Human Resource Development (MHRD-FAST CoE) (F.No.5-5/2014-TSVII), GOI, New Delhi.

DuBois, M., Gilles, K. A., Hamilton, J. K., Rebers, P. A., and Smith, F. (1956) Colorimetric method for determination of sugars and related substances. Anal. Chem. 28, 350-356. doi: 10.1021/ac60111a017

Ehrlich, H., Koutsoukos, P. G., Demadis, K. D., and Pokrovsky, O. S. (2008) Principles of demineralization: modern strategies for the isolation of organic frameworks: Part I. Common definitions and history. Micron 39, 1062-1091. doi: 10.1016/j.micron.2008.02.004

Fasim, F., Ahmed, N., Parsons, R., and Gadd, G. M. (2002). Solubilization of zinc salts by a bacterium isolated from the air environment of a tannery. FEMS Microbiol. Lett. 213, 1-6. doi: 10.1111/j.1574-6968.2002.tb11 277.x

Friis, A. K., Davis, T. A., Figueira, M. M., Paquette, J., and Mucci, A. (2003). Influence of Bacillus subtilis cell walls and EDTA on calcite dissolution rates and crystal surface features. Environ. Sci. Technol. 37, 2376-2382. doi: $10.1021 /$ es026171g

Garcia-Pichel, F. (2006). Plausible mechanisms for the boring on carbonates by microbial phototrophs. Sediment. Geol. 185, 205-213. doi: 10.1016/j.sedgeo.2005.12.013

Gharaibeh, M. A., Eltaif, N. I., and Albalasmeh, A. A. (2011). Reclamation of highly calcareous saline sodic soil using Atriplex halimus and by-product gypsum. Int. J. Phytoremediation 13, 873-883. doi: 10.1080/15226514.2011.573821

Goldstein, A. H. (1995). Recent progress in understanding the molecular genetics and biochemistry of calcium phosphate solubilization by gram negative bacteria. Biol. Agric. Hortic. 12, 185-193. doi: 10.1080/01448765.1995.9754736

Hasanuzzaman, M., Nahar, K., Alam, M. M., Bhowmik, P. C., Hossain, M. A. Rahman, M. M., et al. (2014). Potential use of halophytes to remediate saline soils. Biomed Res. Int. 2014, 12. doi: 10.1155/2014/589341

Haynes, R., and Hamilton, C. (1999). Effects of sugarcane production on soil quality: a synthesis of world literature. Proc. South Afr. Sugar Technol. Assoc. 73, 45-51.

Hopkins, C. G., and Whiting, A. L. (1916). Soil bacteria and phosphates. Science 44, 246-249. doi: 10.1126/science.44.1129.246

Jackson, M. L. (2005). Soil Chemical Analysis: Advanced Course. Madison, WI: UW-Madison Libraries Parallel Press.

Jacobson, A. D., and Wu, L. (2009). Microbial dissolution of calcite at T $=28{ }^{\circ} \mathrm{C}$ and ambient pCO2. Geochim. Cosmochim. Acta 73, 2314-2331. doi: 10.1016/j.gca.2009.01.020

Kraemer, S. M. (2004). Iron oxide dissolution and solubility in the presence of siderophores. Aquat. Sci. 66, 3-18. doi: 10.1007/s00027-003-0690-5

Kreitzman, S. N., and Fritz, M. E. (1970). Demineralization of bone by phosphoprotein phosphatase. J. Dent. Res. 49, 1509-1512. doi: 10.1177/00220345700490065901

Li, W., Yu, L.-J., He, Q. F., Wu, Y., Yuan, D.-X., and Cao, J.-H. (2005). Effects of microbes and their carbonic anhydrase on $\mathrm{Ca} 2+$ and $\mathrm{Mg} 2+$ migration in 
column-built leached soil-limestone karst systems. Appl. Soil Ecol. 29, 274-281. doi: 10.1016/j.apsoil.2004.12.001

Liermann, L. J., Kalinowski, B. E., Brantley, S. L., and Ferry, J. G. (2000). Role of bacterial siderophores in dissolution of hornblende. Geochim. Cosmochim. Acta 64, 587-602. doi: 10.1016/S0016-7037(99) 00288-4

Lüttge, A., and Conrad, P. G. (2004). Direct observation of microbial inhibition of calcite dissolution. Appl. Environ. Microbiol. 70, 1627-1632. doi: 10.1128/AEM.70.3.1627-1632.2004

MacInnis, I. N., and Brantley, S. L. (1992). The role of dislocations and surface morphology in calcite dissolution. Geochim. Cosmochim. Acta 56, 1113-1126. doi: 10.1016/0016-7037(92)90049-O

Mihalache, G., Zamfirache, M. M., Mihasan, M., Ivanov, I., Stefan, M., and Raus, L. (2015). Phosphate-solubilizing bacteria associated with runner bean rhizosphere. Arch. Biol. Sci. 67, 793-800. doi: 10.2298/ABS14100 $3038 \mathrm{M}$

Murtaza, G., Ghafoor, A., Owens, G., Qadir, M., and Kahlon, U. Z. (2009). Environmental and economic benefits of saline-sodic soil reclamation using low-quality water and soil amendments in conjunction with a rice-wheat cropping system. J. Agron. Crop Sci. 195, 124-136. doi: 10.1111/j.1439-037X.2008.00350.x

Murtaza, G., Murtaza, B., Usman, H. M., and Ghafoor, A. (2013). Amelioration of saline-sodic soil using gypsum and low quality water in following sorghumberseem crop rotation. Int. J. Agric. Biol. 15, 640-648.

Newton, R. C., and Manning, C. E. (2002). Experimental determination of calcite solubility in $\mathrm{H} 2 \mathrm{O}-\mathrm{NaCl}$ solutions at deep crust/ upper mantle pressures and temperatures: implications for metasomatic processes in shear zones. Am. Mineral. 87, 1401-1409. doi: 10.2138/am-2002-1016

Ogbo, F. C. (2010). Conversion of cassava wastes for biofertilizer production using phosphate solubilizing fungi. Bioresour. Technol. 101, 4120-4124. doi: 10.1016/j.biortech.2009.12.057

Oster, J. (1982). Gypsum usage in irrigated agriculture: a review. Fertil. Res. 3, 73-89. doi: 10.1007/BF01063410

Parrello, D., Zegeye, A., Mustin, C., and Billard, P. (2016). Siderophore-mediated iron dissolution from nontronites is controlled by mineral cristallochemistry. Front. Microbiol. 7:423. doi: 10.3389/fmicb.2016.00423

Payne, S. M. (1994). Detection, isolation, and characterization of siderophores. Methods Enzymol. 235, 329-344. doi: 10.1016/0076-6879(94) 35151-1

Peacock, A. D., Chang, Y. J., Istok, J. D., Krumholz, L., Geyer, R., Kinsall, B., et al. (2004). Utilization of microbial biofilms as monitors of bioremediation. Microb. Ecol. 47, 284-292. doi: 10.1007/s00248-003-1024-9

Piper, A. M. (1944). A graphic procedure in the geochemical interpretation of water-analyses. Eos Trans. Am. Geophys. Union 25, 914-928. doi: 10.1029/TR025i006p00914

Qadir, M., Noble, A. D., Oster, J. D., Schubert, S., and Ghafoor, A. (2005). Driving forces for sodium removal during phytoremediation of calcareous sodic and saline-sodic soils: a review. Soil Use Manage. 21, 173-180. doi: 10.1079/SUM2005312

Qadir, M., and Oster, J. (2002). Vegetative bioremediation of calcareous sodic soils: history, mechanisms, and evaluation. Irrigation Sci. 21, 91-101. doi: 10.1007/s00271-001-0055-6

Qadir, M., Oster, J. D., Schubert, S., Noble, A. D., and Sahrawat, K. L. (2007). Phytoremediation of sodic and saline-sodic soils. Adv. Agron. 96, 197-247. doi: 10.1016/S0065-2113(07)96006-X

Richards, L. A. (1954). Diagnosis and improvement of saline and alkali soils. Soil Sci. 78, 154. doi: 10.1097/00010694-195408000-00012

Sambrook, J., Fritsch, E. F., and Maniatis, T. (1989). Molecular Cloning. New York, NY: Cold Spring Harbor Laboratory Press.

Schwyn, B., and Neilands, J. (1987). Universal chemical assay for the detection and determination of siderophores. Anal. Biochem. 160, 47-56. doi: 10.1016/0003-2697(87)90612-9
Shainberg, I., Sumner, M. E., Miller, W. P., Farina, M. P. W., Pavan, M. A., and Fey, M. V. (1989). "Use of gypsum on soils: a review," in Advances in Soil Science, ed B. A. Stewart (New York, NY: Springer), 1-111.

Sharma, D. P., and Rao, K. V. G. K. (1998). Strategy for long term use of saline drainage water for irrigation in semi-arid regions. Soil Tillage Res. 48, 287-295. doi: 10.1016/S0167-1987(98)00135-4

Shirvani, M., and Nourbakhsh, F. (2010). Desferrioxamine-B adsorption to and iron dissolution from palygorskite and sepiolite. Appl. Clay Sci. 48, 393-397. doi: 10.1016/j.clay.2010.01.012

Sonntag, G. (2015). An Analysis of Microbial Involvement in Biospeleogenesis within Lechuguilla Cave System. Honors Research Project, Paper 165, Department of Biology, The University of Akron, USA.

Subrahmanyam, G. (2013). Bacterial Diversity and Activity of Semiarid Soils of Mahi River Basin, Western India. Ph.D. thesis. The Maharaja Sayajirao University of Baroda, Gujarat, India.

Subrahmanyam, G., Vaghela, R., Bhatt, N. P., and Archana, G. (2012). Carbonate-dissolving bacteria from'miliolite', a bioclastic limestone, from Gopnath, Gujarat, Western India. Microb. Environ. 27, 334-337. doi: 10.1264/jsme2.ME11347

Sulu-Gambari, F. (2011). Bacterially-Induced Dissolution of Calcite: The Role of Bacteria in Limestone Weathering. Montreal, QC: McGill University Libraries.

Sumner, M. E. (1993). Sodic soils-New perspectives. Soil Res. 31, 683-750. doi: $10.1071 /$ SR9930683

Tabatabai, M. A., and Bremner, J. M. (1969). Use of p-nitrophenyl phosphate for assay of soil phosphatase activity. Soil Biol. Biochem. 1, 301-307. doi: 10.1016/0038-0717(69)90012-1

Tamura, K., Stecher, G., Peterson, D., Filipski, A., and Kumar, S. (2013). MEGA6: molecular evolutionary genetics analysis version 6.0. Mol. Biol. Evol. 30, 2725-2729. doi: 10.1093/molbev/mst197

Tazeh, E. S., Pazira, E., Neyshabouri, M. R., Abbasi, F., and Abyaneh, H. Z. (2013). Effects of two organic amendments on EC, SAR and soluble ions concentration in a saline-sodic soil. Int. J. Biosci. 3, 55-68. doi: 10.12692/ijb/3.9.55-68

Teng, H. H., Chen, Y., and Pauli, E. (2006). Direction specific interactions of 1, 4-dicarboxylic acid with calcite surfaces. J. Am. Chem. Soc. 128, 14482-14484. doi: $10.1021 / \mathrm{ja} 063167 \mathrm{~m}$

USEPA (2000). Government Report: Introduction to Phytoremediation. The U.S. Environmental Protection Agency.

Whitelaw, M. A., Harden, T. J., and Helyar, K. R. (1999). Phosphate solubilisation in solution culture by the soil fungus Penicillium radicum. Soil Biol. Biochem. 31, 655-665. doi: 10.1016/S0038-0717(98)00130-8

XLSTAT (2010). Addinsoft SARL, Paris. Available online at http://www.xlstat.com

Yi, Y., Huang, W., and Ge, Y. (2008). Exopolysaccharide: a novel important factor in the microbial dissolution of tricalcium phosphate. World J. Microbiol. Biotechnol. 24, 1059-1065. doi: 10.1007/s11274-007-9575-4

Yoshida, T., Hayashi, K.-I., and Ohmoto, H. (2002). Dissolution of iron hydroxides by marine bacterial siderophore. Chem. Geol. 184, 1-9. doi: $10.1016 /$ S0009-2541(01)00297-2

Conflict of Interest Statement: The authors declare that the research was conducted in the absence of any commercial or financial relationships that could be construed as a potential conflict of interest.

The handling Editor declared a shared affiliation, though no other collaboration, with the authors and states that the process nevertheless met the standards of a fair and objective review.

Copyright $\odot 2016$ Tamilselvi, Thiyagarajan and Uthandi. This is an open-access article distributed under the terms of the Creative Commons Attribution License (CC $B Y)$. The use, distribution or reproduction in other forums is permitted, provided the original author(s) or licensor are credited and that the original publication in this journal is cited, in accordance with accepted academic practice. No use, distribution or reproduction is permitted which does not comply with these terms. 